\title{
Benthic macroinvertebrate community structure in a stream of the north-west region of Paraná State, Brazil
}

\author{
Yara Moretto Bagatini ${ }^{1,4}$, Rosilene Luciana Delariva ${ }^{2}$ \& Janet Higuti ${ }^{3}$ \\ ${ }^{1}$ Universidade Federal do Paraná - UFPR, Rua Pioneiro, Jardim Dallas, \\ Campus Palotina, CEP 85950-000, Palotina, PR, Brazil \\ ${ }^{2}$ Centro de Ciências Biológicas e da Saúde, Universidade Estadual do Oeste do Paraná - UNIOESTE, \\ Rua Universitária, 2069, Bairro Universitário, CEP 85819-110, Cascavel, PR, Brazil \\ ${ }^{3}$ Núcleo de Pesquisas em Limnologia, Ictiologia e Aquicultura - NUPÉLIA, \\ Universidade Estadual de Maringá - UEM, Av. Colombo, 5790, Bloco H-90, CEP 87020-900, Maringá, PR, Brazil \\ ${ }^{4}$ Corresponding author: Yara Moretto Bagatini,e-mail: ymorettob@gmail.com
}

BAGATINI, Y.M., DELARIVA, R.L. \& HIGUTI J. Benthic macroinvertebrate community structure in a stream of the north-west region of Paraná State, Brazil. Biota Neotrop. 12(1): http://www.biotaneotropica. org.br/v12n1/en/abstract?short-communication+bn00912012012

\begin{abstract}
This study aimed to survey the benthic macroinvertebrate fauna of a first order stream located in an agricultural area, and to assess the environmental factors involved in the spatial distribution of this community. Invertebrates were gathered in November 2007 at three sampling sites distributed along the Itiz Stream, located in Marialva municipality, Paraná State. At each site, we measured the physical and chemical variables of the water, and then took four samples, using Surber sampler. In order to evaluate the differences in density, richness, diversity and evenness, we employed an ANOVA and a DCA to summarize biotic data. The invertebrates were categorized into functional groups and the BMWP score was applied to calculate the biological integrity of the environment. The faunal composition was represented by 103 taxa distributed across five phyla, of which the highest occurrence was of arthropods, especially insects. Higher density values were observed for Chironomidae, Ephemeroptera, Coleoptera and Trichoptera. The richness, diversity and density, as well as the density of gatheringcollectors, were higher in the intermediate course of the stream. The distribution pattern of the taxa was mainly influenced by lentic or lotic characteristics of the sampled sites and microhabitats, as evidenced by the DCA. The BMWP indices indicated that the three sampling sites presented scores of excellent and good water quality. In the Itiz Stream, the presence of preserved marginal vegetation and the distance from urban centers that generate pollution, combined with peculiarities of each sampling site, influenced the structure of the benthic community. Keywords: composition, biomonitoring, functional groups, aquatic insects.
\end{abstract}

BAGATINI, Y.M., DELARIVA, R.L. \& HIGUTI J. Estrutura da comunidade de macroinvertebrados bentônicos em um riacho da região noroeste do Paraná, Brasil. Biota Neotrop. 12(1): http://www. biotaneotropica.org.br/v12n1/pt/abstract?short-communication+bn00912012012

Resumo: O objetivo deste estudo foi inventariar a fauna de macroinvertebrados bentônicos de um riacho de primeira ordem, situado em uma área agrícola, e avaliar os fatores ambientais intervenientes na distribuição espacial dessa comunidade. Os invertebrados foram coletados em novembro de 2007 em três pontos de amostragem distribuídos ao longo do riacho Itiz, localizado no município de Marialva, Paraná. Em cada ponto, foram medidas as variáveis físicas e químicas da água e em seguida, quatro amostras foram retiradas usando o amostrador Surber. Para avaliar diferenças entre a densidade, a riqueza, a diversidade e a equitabilidade, utilizou-se a ANOVA e uma DCA para sumarizar os dados bióticos. Os invertebrados foram categorizados em grupos funcionais e o índice BMWP foi aplicado para calcular a integridade biológica desse ambiente. A composição faunística foi representada por 103 táxons distribuídos em cinco filos, dos quais a maior ocorrência foi de artrópodes, especialmente os insetos. Os maiores valores de densidades foram observados para Chironomidae, Ephemeroptera, Coleoptera e Trichoptera. A riqueza, diversidade e densidade foram maiores na região intermediária do riacho, assim como a maior densidade dos coletores. O padrão de distribuição dos táxons foi principalmente influenciado pelas características lênticas ou lóticas dos pontos de coleta e dos microhabitats amostrados, como evidenciado pela DCA. Os resultados do índice BMWP indicaram que os três pontos de amostragem, apresentaram qualidade de água variando de excelente a boa. No riacho Itiz a presença de vegetação marginal preservada e a sua distância de centros urbanos geradores de poluição, aliada às peculiaridades de cada ponto de amostragem influenciaram na estruturação da comunidade bentônica e também contribuíram para a elevada qualidade da água em todos os pontos amostrados. Palavras-chave: composição, biomonitoramento, grupos funcionais, insetos aquáticos. 


\section{Introduction}

The ecological integrity of rivers and streams has become a subject of key importance for the maintenance of these resources worldwide (Monteiro et al. 2008). Nevertheless, this requires knowledge about patterns of diversity and abundance of communities that comprise these ecosystems, given that many of them provide evidence of the conditions of environmental preservation of their location.

The benthic macroinvertebrate fauna, which involves numerous taxonomic groups, is an important link in the energy flow from the deep compartment to the aquatic environment. Additionally, these invertebrates are a modern tool frequently used for the monitoring of freshwater aquatic ecosystems (Baptista 2008); this fact is related to their traits and ecological requirements, especially since they are ubiquitous (Lenat et al. 1980), of sedentary nature, with a distribution that may be influenced by some physical or chemical disturbance (Abel 1989, Milesi et al. 2009), and by substrate characteristics (Buss et al. 2004), and they are found in leaves, branches, rocks and associated with aquatic plants (Würdig et al. 2007).

In streams, where in general the surrounding riparian vegetation is preserved and the geomorphological characteristics allow the formation of areas of backwater and riffles, several microhabitats are observed and these locations provide shelter and abundant food resource for a higher diversity of taxonomic groups. According to Vannotte et al. (1980), the richness and taxonomic diversity are in general composed of organisms belonging to several functional groups, which are modified according to the gradient and morphological changes in the order of the streams. In the context of the River Continuum Concept (RCC), initially proposed by Vannote et al. (1980), the composition of functional feeding groups could change with the longitudinal gradient, the order of the stream (Heino et al. 2005) and also with species traits (Poff 1997). In this way, macroinvertebrate classification by functional category can provide a better understanding of the functioning of the food web and indirectly help to evaluate water quality.

In stream aquatic biomonitoring, the Biological Monitoring Working Party (BMWP) is an index widely used to detect mainly organic pollution, across a score system attributed to macroinvertebrates families considering their tolerance or sensibility to organic pollutants (Alba-Tecedor 1996). Some studies pointed out that, in comparison with other metrics, the BMWP indices, provide better results for benthic fauna (Guimarães et al. 2009, Silva et al. 2011).

The present study aimed to survey the benthic macroinvertebrate fauna of a first order stream in the north-west region of Paraná State, and evaluate the water quality through the BMWP indices. We predicted that the fauna would be composed especially of organisms whose spatial distribution is mainly influenced by the characteristics of the substrate, organic matter and of abiotic variables, and whose functional category is in accordance with the River Continuum Concept.

\section{Material and Methods}

\section{Study area}

Samplings were undertaken in Itiz Stream, a small water course located in Marialva municipality, Paraná State, which belongs to the Ivaí River watershed (Figure 1). This environment is a first order stream, where we established three samplings sites in stretches of $50 \mathrm{~m}$, with an approximate distance of $1.2 \mathrm{~km}$ between each station.

Upstream, named as site 1 ( $23^{\circ} 31^{\prime} 49.9^{\prime \prime} \mathrm{S}$ and $\left.51^{\circ} 46^{\prime} 26.9^{\prime \prime} \mathrm{W}\right)$, is located in the upper stretch of the stream, with riffles, mean depth of $0.20,2.5 \mathrm{~m}$ wide and pools at up to $0.60 \mathrm{~m}$. The riparian vegetation is tree-shrub type and promotes ca. $80 \%$ shading in the sampled environment. The substrate is mainly composed of gravel, sand and silt, as well as leaves and branches submerged in the bed. The water is used for irrigation in the surroundings near to the sampled stretch.

Intermediate, named as site $2\left(23^{\circ} 32^{\prime} 11.2^{\prime \prime} \mathrm{S}\right.$ and $\left.51^{\circ} 46^{\prime} 59^{\prime \prime} \mathrm{W}\right)$, has an upstream waterfall of about $1.5 \mathrm{~m}$ height, followed by a pool of about $5 \mathrm{~m}$ wide and up to $1.20 \mathrm{~m}$ depth. There are riffle areas with rocky bottom, pebbles and granules, with a depth from 0.10 to $0.20 \mathrm{~m}$, a width of $2 \mathrm{~m}$ and a few backwater areas. On the banks, the vegetation is tree-shrub type, $80 \%$ shading, with little aquatic vegetation. The substrate is composed of $80 \%$ pebbles and, in some backwaters, of mud.

Downstream, named as site $3\left(23^{\circ} 32^{\prime} 02.6^{\prime} \mathrm{S}\right.$ and $51^{\circ} 47^{\prime} 26.3^{\prime \prime} \mathrm{W}$ ), has riffle areas with pebbles and granules, depth from 0.10 to $0.20 \mathrm{~m}$ and $3 \mathrm{~m}$ wide. Most of the substrate presents a muddy bottom with submerged leaves and depth ranging from 0.30 to $0.50 \mathrm{~m}$. Downstream of the $50 \mathrm{~m}$ stretch that we sampled, there was a waterfall of about $1.5 \mathrm{~m}$ in height. The vegetation on the banks is tree-shrub type with grasses, with ca. $70 \%$ shading, this being the stretch with the lowest proportion of riparian vegetation $(10 \mathrm{~m}$ at each bank).

\section{Field sampling}

Benthic macroinvertebrates were gathered in November 2001 at three sampling sites (upstream, intermediate and downstream) in Itiz Stream. At each site, four samples were taken using a Surber sampler $\left(0.09 \mathrm{~m}^{2}\right), 250 \mathrm{~mm}$ mesh size, and stored in labeled polyethylene flasks. In the laboratory, samples were sorted using an overlapping sieve system (4 and $0.250 \mathrm{~mm}$ mesh size) and the retained material in the smallest mesh was fixed in $4 \%$ formaldehyde buffered with calcium carbonate, for posterior sorting under a stereoscopic microscope.

The values of water temperature and dissolved oxygen (YSI oximeter), $\mathrm{pH}$ (Digimed pHmeter) and electric conductivity (Digimed conductivimeter) were measured at the three sampling sites. Moreover, a description of the microhabitats was made at each sampling site (Table 1).

\section{Laboratory analysis}

The benthic microorganisms were sorted, identified and counted under stereoscopic and optical microscopes. Identification of benthic invertebrates was based on Pérez (1987), McCafferty (1988), Peckarsky et al. (1990), Brinkhurst \& Marchese (1991), Thorp \& Covich (1991), Martens (1995), Trivinho-Strixino \& Strixino (1995), Merritt \& Cummins (1996), Rossetti \& Martens (1996, 1998), and Pes et al. (2005).

\section{Data analysis}

The Shannon-Wiener diversity index, described by the equation $\mathrm{H}^{\prime}=-\Sigma(\mathrm{ni} / \mathrm{N}) \cdot \log _{2}(\mathrm{ni} / \mathrm{N})$, where $n i$ is the number of individuals in species $i$, and $N$ is the total number of all individuals; and the evenness, obtained through the expression $\mathrm{H}^{\prime} / \mathrm{Hmax}$, where Hmáx is the diversity under maximum condition of uniformity (Magurran 1988), were calculated for the different sampling sites.

A parametric ANOVA was carried out to test possible differences in richness, density, diversity and evenness between sampling sites, using the software Statisoft version 7.1 (StatSoft Inc. 2005).

A Detrended Correspondence Analysis (DCA) was carried out to search for patterns in the distribution of benthic invertebrates in Itiz Stream. Ordination of sampling sites, based on the density of invertebrates, was performed to reduce the dimensionality of biotic 


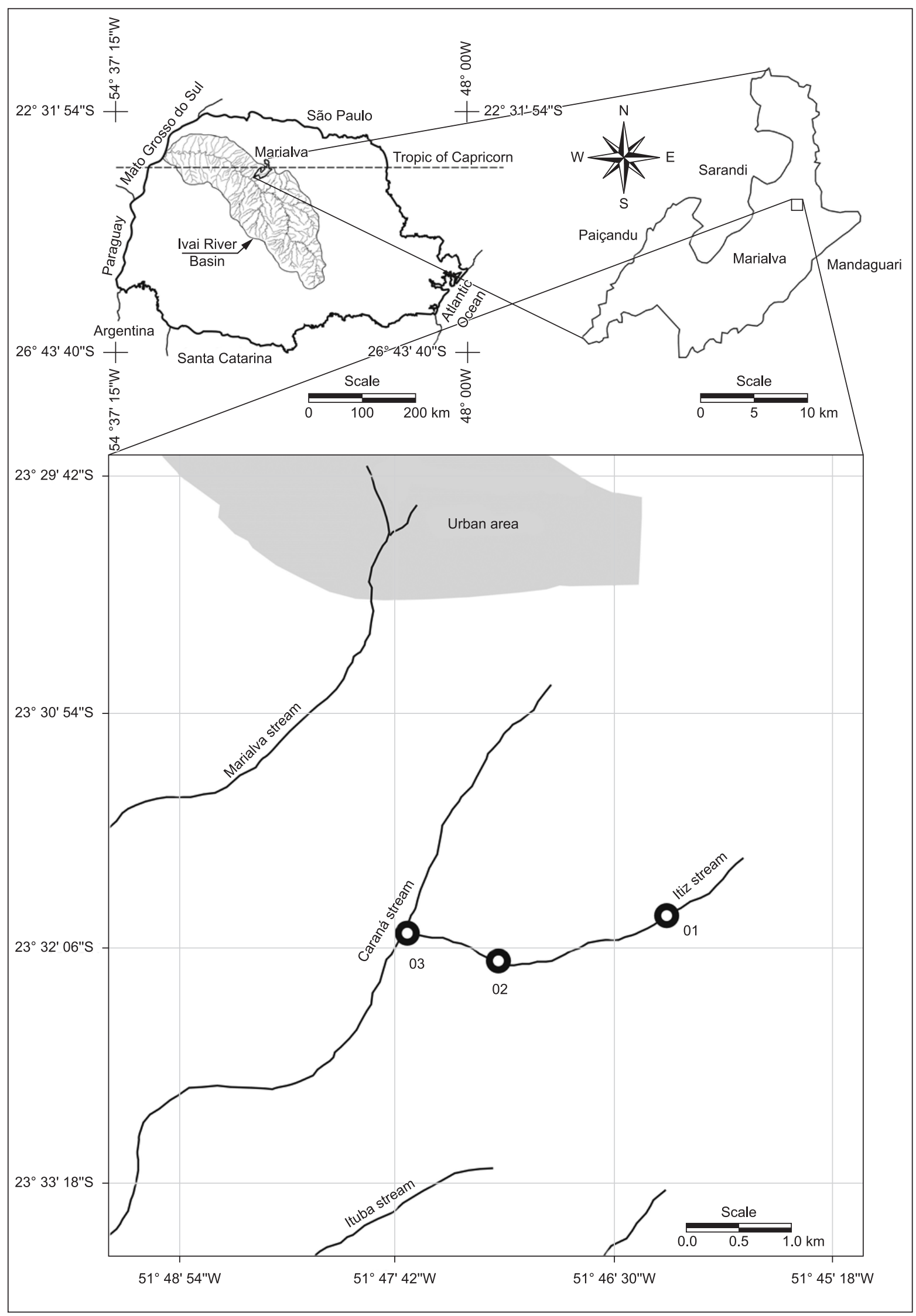

Figure 1. Location of sampling sites along Itiz Stream, Marialva municipality. 
Table 1. Values of abiotic variables and the microhabitats of the sampling sites of Itiz Stream, in November 2007.

\begin{tabular}{|c|c|c|c|c|c|c|c|}
\hline Itiz stream & Samples & D (cm) & $\mathbf{T}\left({ }^{\circ} \mathbf{C}\right)$ & DO $\left(\mathrm{mg} . \mathrm{L}^{-1}\right)$ & $\mathrm{EC}\left(\mu \mathrm{S} . \mathrm{cm}^{-1}\right)$ & pH & Substrate type \\
\hline \multirow[t]{4}{*}{ Upstream } & U1 & 5 & 22 & 7.7 & 124.1 & 7.2 & $\mathrm{P}$ \\
\hline & $\mathrm{U} 2$ & 5 & 22 & 7.7 & 124.1 & 7.2 & $\mathrm{P} / \mathrm{L}$ \\
\hline & U3 & 10 & 22 & 7.7 & 124.1 & 7.2 & $\mathrm{P}$ \\
\hline & U4* & 5 & 22 & 7.7 & 124.1 & 7.2 & $\mathrm{M} / \mathrm{L}$ \\
\hline \multirow[t]{4}{*}{ Intermediate } & I1 & 5 & 22 & 8.2 & 138.4 & 7.4 & $\mathrm{P} / \mathrm{L}$ \\
\hline & $\mathrm{I} 2$ & 5 & 22 & 8.2 & 138.4 & 7.5 & $\mathrm{P}$ \\
\hline & $\mathrm{I} 3$ & 5 & 22 & 8.2 & 138.4 & 7.5 & $\mathrm{P} / \mathrm{L}$ \\
\hline & I $4 *$ & 25 & 22 & 8.2 & 138.4 & 7.5 & $\mathrm{M} / \mathrm{L} / \mathrm{R}$ \\
\hline \multirow[t]{4}{*}{ Downstream } & D1 & 5 & 23 & 7.9 & 139.7 & 7.3 & $\mathrm{P} / \mathrm{G} / \mathrm{S}$ \\
\hline & D2 & 10 & 23 & 7.9 & 139.7 & 7.3 & $\mathrm{P} / \mathrm{S}$ \\
\hline & D3 & 5 & 23 & 7.9 & 139.7 & 7.3 & P/G/S/L \\
\hline & D4* & 20 & 23 & 7.9 & 139.7 & 7.3 & $\mathrm{M} / \mathrm{L}$ \\
\hline
\end{tabular}

D: depth, T: water temperature, DO: dissolved oxygen, EC: electric conductivity and; *backwater area. Substrate types: P: pebble; G: gravel; S: sandy; L:

litter; M: mud; R: routs, U: upstream, I: intermediate, D: downstream.

data. These data were previously transformed into $\log [\log (x+1)]$ to minimize outlier effects. The analysis was undertaken with the aid of PC-ORD version 4.01 (McCune \& Mefford 1999).

The invertebrates were classified into functional feeding groups (FFG), gathering-collector, filtering-collector, predator, scraper and shredder, based on Brazilian and Neotropical literature (Fernández \& Domínguez 2001, Cummins et al. 2005, Costa et al. 2006, Wantzen \& Wagner 2006). For those taxa belonging to more than one functional group, the individuals were divided between each possible trophic category (Ligeiro et al. 2010a). Nematoda, Diptera and Ostracoda were not classified due to their many feeding habits. In an attempt to classify the water quality, according to the macroinvertebrate species present, we also employed the Biological Monitoring Working Party (BMWP) index, adapted by Loyola (2000), a method which considers the presence of families of invertebrates and assigns them scores, according to organisms' sensitivity to organic pollution.

\section{Results}

Values of water temperature, dissolved oxygen, electrical conductivity and $\mathrm{pH}$ varied somewhat between sampling sites. Nevertheless, higher concentrations of dissolved oxygen were recorded in the intermediate course. The microhabitats differed mainly in respect of litter presence. Besides that, in general, we verified greater depths in sections with low velocities of current, and therefore with the presence of fine particles of sediment (mud)

Faunal composition was represented by 103 taxa belonging to five phyla, most of which have been verified for arthropods, especially Chironomidae and Ephemeroptera, in all sampling sites (Table 2). Noteworthy was the presence of a probable new genus and species of Ostracoda, from the Cyprididae family (Cyprididae n.gen $n$. sp.), (Higuti, J. personal communication; voucher specimens were deposited in the Laboratory of Ostracoda from the State University of Maringá), which was recorded in the upstream and intermediate course (Table 2.)

Higher density values were observed for insects $\left(33,067\right.$ ind. $\left.\mathrm{m}^{-2}\right)$, among them, mainly Chironomidae (12,100 ind. $\left.\mathrm{m}^{-2}\right)$, Ephemeroptera $\left(9,300\right.$ ind. $\left.\mathrm{m}^{-2}\right)$, Coleoptera $\left(5,667\right.$ ind. $\left.\mathrm{m}^{-2}\right)$ and Trichoptera $\left(3,222\right.$ ind. $\left.\mathrm{m}^{-2}\right)$ (Figure 2).

The highest values of richness, density and diversity were registered in the intermediate course of the Itiz Stream, except for evenness (Figure 3). Furthermore, some taxa, mainly Thraulodes, Chimarra, Corynoneura and Perlidae, were unique to this site

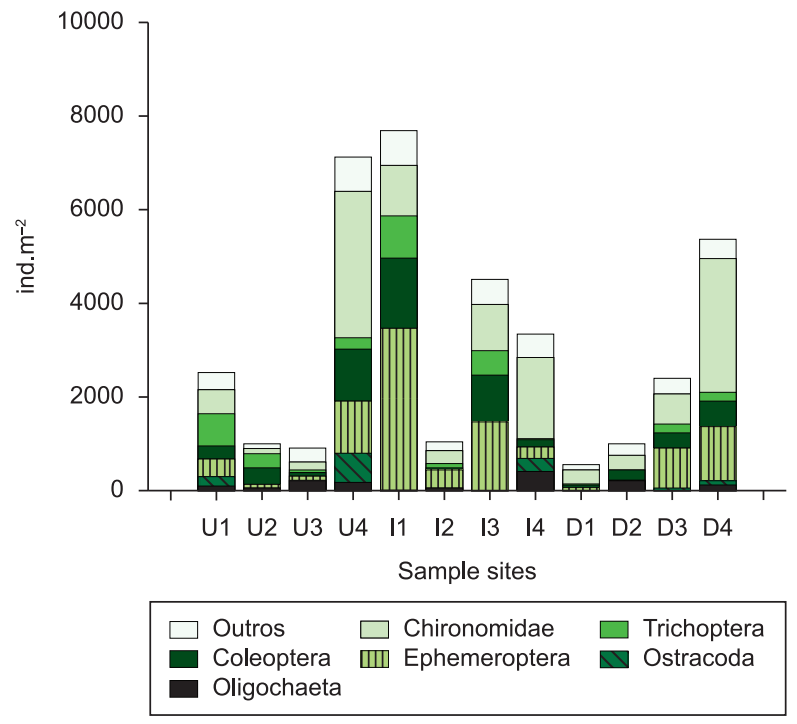

Figure 2. Density of benthic invertebrates in the different sampling sites of Itiz Stream, during the study period U: upstream, I: intermediate, D: downstream, $1,2,3,4$ : sample number.

(Table 2). However, the ANOVA results did not evidence significant differences between sampling sites for all analyzed attributes (Figure 3).

Axes 1 and 2 of the DCA presented eigenvalues of 0.64 and 0.21 , respectively. Benthic invertebrates were ordinated according to their occurrence and density at the different sampling sites. It was therefore possible to distinguish a group (group I) ordinated by the locations with lentic characteristics (C4, I4 and F4), mainly formed by organisms (some Oligochaeta, Ostracoda, Chironomidae) more adapted to environments with a lower, but well-oxygenated, current. The groups II, III and IV were ordinated according to sampling sites in the upstream, intermediate and downstream sites, respectively (Figure 4).

Invertebrates were classified according to functional feeding groups, namely: filtering-collector, gathering-collector, shredder, scrapers and predator. Gathering-collectors were the most abundant in all sampling sites, with higher densities in the intermediate course $\left(2.192\right.$ ind. $\left.\mathrm{m}^{-2}\right)$, followed by scrapers, filtering-collectors 
Table 2. Occurrence of benthic invertebrates in Itiz Stream. Taxa abbreviations are in parentheses.

Filo Platyhelminthes

Turbellaria (Tur)

Filo Nematoda (Nem)

Filo Mollusca

Gastropoda

Ancylidae (Anc)

Physidae

Stenophysa (Ste)

Planorbidae (Pla)

Bivalvia

Pisidiidae

Pisidium (Pis)

Filo Annelida

Oligochaeta

Alluroididae

Brinkhurstia americanus (Bam)

Enchytraeidae (Enc)

Naididae

Pristina breviseta (Pbr)

Stephensoniana trivandrana (Str)

Tubificidae

Aullodrilus piguetii (Api)

Bothrioneurum americanum (Boa)

Branchiura sowerbyi (Bso)

Filo Arthropoda

Prostigmata

Hydrozetes (Hyd)

Limnesia (Lim)

Piona (Pio)

Prostigmata sp.4 (Pr4)

ninfa de Prostigmata

Sub-filo Crustacea

Ostracoda

Cyprididae

Cypridopsis vidua (Cyp)

Stenocypris major (Sma)

Stenocypris sp.2 (St2)

Cyprididae n.gen n.sp. (Cyn)

Candonidae

Candonopsis brasiliensis (Cbr)

Darwinulidae

Darwinula stevensoni (Dst)

Penthesilenula aotearoa (Pao)

Vestalenula pagliolii (Vpa)

Copepoda

Cyclopoida (Cyc)

Amphipoda (Amp)

Classe Insecta

Ephemeroptera

Caenidae

Caenis (Cae)

Leptohyphidae

Tricorythodes (Tric)

Leptophlebiidae

\section{Upstream}

$+$

+
+

$+$

$+$

$+$

$+$

$+$

$+$

$+$

$+$

$+$

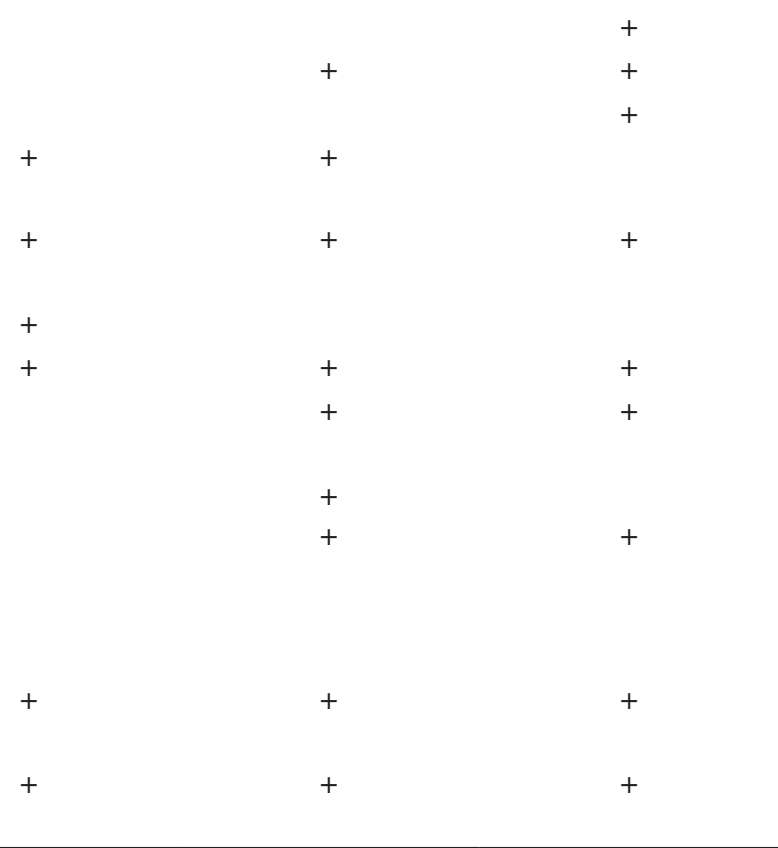

$+$

$+$

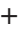

$+$

$+$

$+$

$+$

$+$

Intermediate

Downstream 
Table 2. Continued...

\begin{tabular}{|c|c|c|c|}
\hline & Upstream & Intermediate & Downstream \\
\hline Thraulodes (Thr) & & + & \\
\hline \multicolumn{4}{|l|}{ Odonata } \\
\hline \multicolumn{4}{|l|}{ Anisoptera } \\
\hline \multicolumn{4}{|l|}{ Gomphidae } \\
\hline Phyllocycla (Phy) & & + & \\
\hline Progomphus (Pro) & & & + \\
\hline \multicolumn{4}{|l|}{ Tibiogomphus (Tib) } \\
\hline Libellulidae & & & + \\
\hline Perithemis (Per) & & + & \\
\hline \multicolumn{4}{|l|}{ Zygoptera } \\
\hline \multicolumn{4}{|l|}{ Calopterygidae } \\
\hline Hetaerina (Het) & + & & + \\
\hline \multicolumn{4}{|l|}{ Coenagrionidae } \\
\hline Argia (Arg) & + & & \\
\hline \multicolumn{4}{|l|}{ Megapodagrionidae } \\
\hline Heteragrion (Heg) & & + & \\
\hline \multicolumn{4}{|l|}{ Plecoptera } \\
\hline \multicolumn{4}{|l|}{ Perlidae (Per) } \\
\hline \multicolumn{4}{|l|}{ Hemiptera } \\
\hline \multicolumn{4}{|l|}{ Veliidae } \\
\hline Rhagovelia (Rha) & + & + & + \\
\hline \multicolumn{4}{|l|}{ Megaloptera } \\
\hline Corydalidae (Cor) & & + & + \\
\hline \multicolumn{4}{|l|}{ Coleoptera } \\
\hline \multicolumn{4}{|l|}{ Dryopidae } \\
\hline Helichus (Hel) & + & + & + \\
\hline \multicolumn{4}{|l|}{ Elmidae } \\
\hline Macrelmis (Mac) & + & + & + \\
\hline Elmidae sp.2 (El2) & & + & + \\
\hline Elmidae sp.3 (El3) & & & + \\
\hline Gyrinidae (Gyr) & + & & + \\
\hline \multicolumn{4}{|l|}{ Psephenidae } \\
\hline Psephenus (Pse) & + & & \\
\hline Coleoptera sp.7 (Col) & & & + \\
\hline Coleoptera adulto sp.1 (Cad1) & & + & + \\
\hline Coleoptera adulto sp.2 (Cad2) & & + & \\
\hline Coleoptera adulto sp.3 (Cad3) & & + & \\
\hline Coleoptera adulto sp.4 (Cad4) & & + & \\
\hline \multicolumn{4}{|l|}{ Trichoptera } \\
\hline \multicolumn{4}{|l|}{ Glossomatidae } \\
\hline Protoptila (Prot) & + & + & + \\
\hline \multicolumn{4}{|l|}{ Hydroptilidae } \\
\hline Hydroptila (Hyd) & + & & \\
\hline Neotrichia $(\mathrm{Neo})$ & + & + & \\
\hline Hydropsychidae & & & \\
\hline Leptonema (Lep) & + & + & + \\
\hline Hydrobiosidae & & & \\
\hline Atopsyche (Ato) & + & & \\
\hline Leptoceridae & & & \\
\hline Nectopsyche (Nec) & + & + & + \\
\hline Oecetis (Oec) & + & & + \\
\hline Odontoceridae (Odo) & & + & \\
\hline Philopotamidae & & & \\
\hline Chimarra (Chi) & & + & \\
\hline
\end{tabular}


Table 2. Continued...

\begin{tabular}{|c|c|c|c|}
\hline & Upstream & Intermediate & Downstream \\
\hline \multicolumn{4}{|l|}{ Polycentropodidae } \\
\hline Cyrnellus (Cym) & + & & \\
\hline \multicolumn{4}{|l|}{ Lepidoptera } \\
\hline $\begin{array}{l}\text { Pyralidae (Pyr) } \\
\text { Diptera } \\
\text { Ceratopogonidae }\end{array}$ & & + & + \\
\hline Alluaudomyia (Allu) & + & & \\
\hline Probezzia sp.1 (Pro1) & & + & + \\
\hline Probezzia sp.2 (Pro2) & + & + & \\
\hline $\begin{array}{l}\text { pupa de Ceratopogonidae } \\
\text { Chironomidae } \\
\text { Tanypodinae }\end{array}$ & + & + & + \\
\hline Ablabesmyia (Karelia) (AblaK) & + & + & + \\
\hline Ablabesmyia (Abla) & + & + & + \\
\hline Coelotanypus (Coe) & + & & \\
\hline Djalmabatista (Dja) & & & + \\
\hline Fittkauimyia (Fit) & + & & \\
\hline Labrundinea (Lab) & + & + & + \\
\hline Macropelopia (Mac) & + & & \\
\hline \multicolumn{4}{|l|}{ Chironominae } \\
\hline Cryptochironomus (Cry) & + & & \\
\hline Endotribelos sp.1 (End) & & + & \\
\hline Polypedilum (Poly) & + & + & + \\
\hline Stempellina (Stem) & + & + & \\
\hline Stenochironomus (Sch) & + & & \\
\hline Rheotanytarsus (Rhe) & + & + & + \\
\hline Rheotanytarsus sp.2 (Rhe2) & & & + \\
\hline Tanytarsus (Tany) & + & + & + \\
\hline Zavreliella (Zav) & + & + & + \\
\hline \multicolumn{4}{|l|}{ Orthocladiinae (Orth) } \\
\hline Corynoneura & & + & \\
\hline Cricotopus & & & + \\
\hline Lopescladius & + & + & + \\
\hline Nanocladius & & + & + \\
\hline Thienemaniella sp.3 & + & + & + \\
\hline Orthocladiinae sp.6 (Orth6) & + & + & + \\
\hline Orthocladiinae sp.7 (Orth7) & & + & \\
\hline Orthocladiinae (juv) & & + & \\
\hline $\begin{array}{l}\text { pupa de Chironomidae } \\
\text { Empididae }\end{array}$ & + & + & + \\
\hline Hemerodromia (Heme) & + & + & + \\
\hline \multicolumn{3}{|l|}{ Psychodidae } & + \\
\hline Maruina (Mar) & & + & \\
\hline $\begin{array}{l}\text { Simuliidae (Simu) } \\
\text { pupa de Simuliidae } \\
\text { Tabanidae }\end{array}$ & + & + & $\begin{array}{l}+ \\
+\end{array}$ \\
\hline $\begin{array}{l}\text { Chrysops (Chry) } \\
\text { Tabanidae sp.2 (Taba) } \\
\text { Tipulidae }\end{array}$ & + & & \\
\hline Hexatoma (Eriocera) (Hexa) & & + & \\
\hline Tipulidae sp.2 (Tipu) & & + & \\
\hline
\end{tabular}


Bagatini, Y.M. et al.
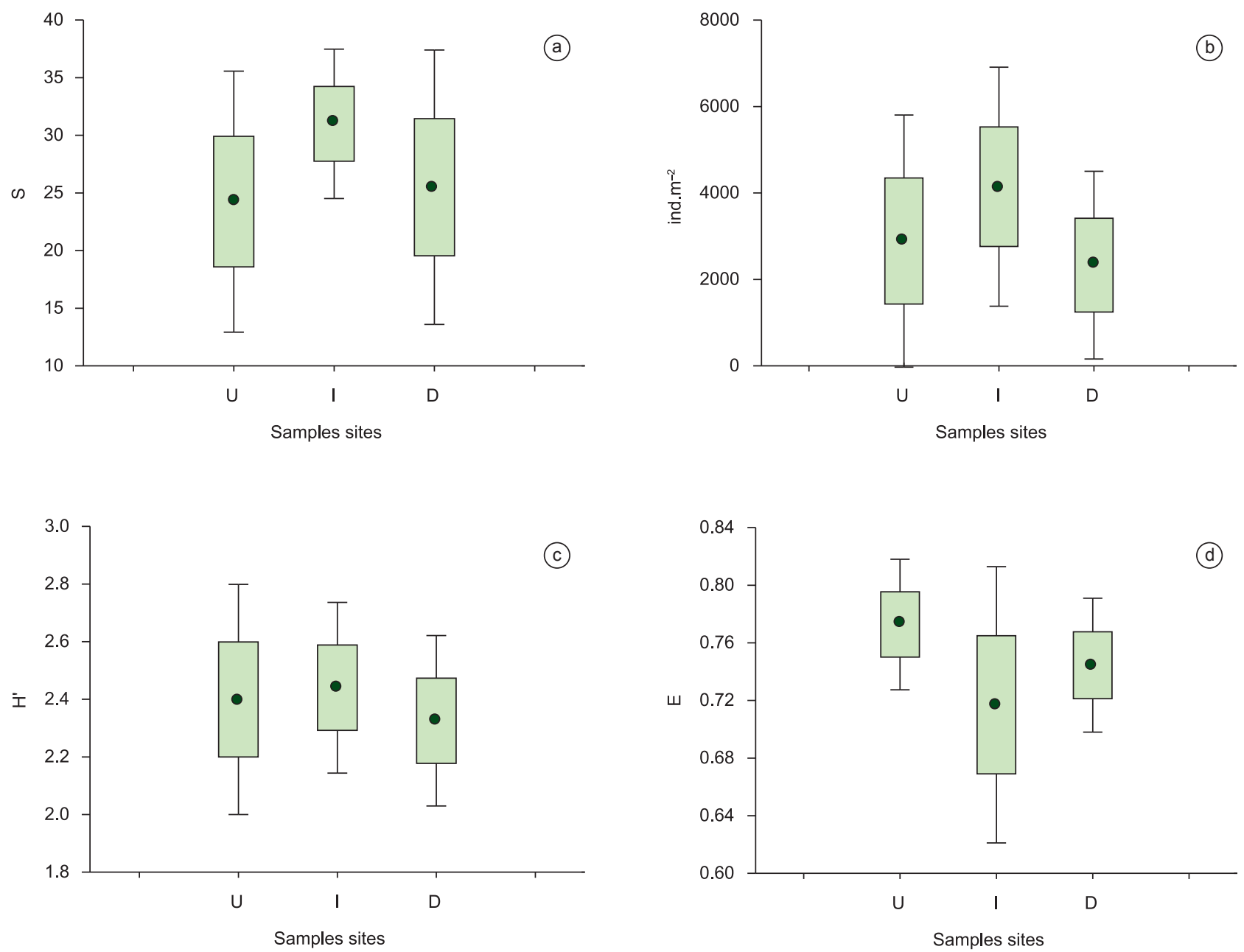

Figure 3. Mean values, standard deviation (bar) and standard error (rectangle) of richness (S), density (ind.m-2), diversity (H') and evenness (E) in the different sampling sites of Itiz Stream. U: upstream, I: intermediate, D: downstream.
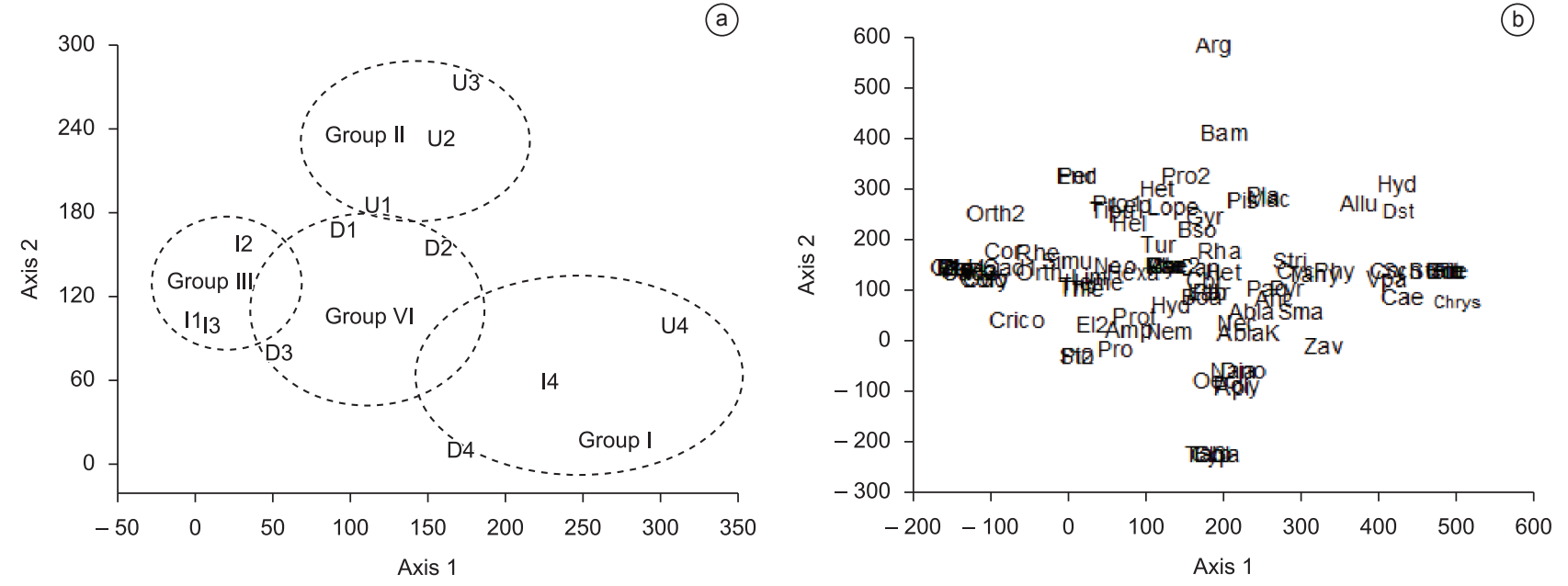

Figure 4. Distribution of DCA scores, derived from density of benthic invertebrates: a) ordination of sampling sites, and b) ordination of invertebrate taxa of Itiz Stream, in November 2007. U: upstream, I: intermediate, D: downstream The abbreviations of taxa are listed in Table 2.

and predators in the upstream and the intemediate course of the Itiz Stream, respectively (Figure 5).

The results of BMWP indices obtained for the Itiz Stream indicated that the three sampling sites, upstream (147), intermediate (175) and downstream (127), presented water quality varying between excellent and good, according to the ascribed score.

\section{Discussion}

There was a low oscillation of the values of physical and chemical variables of the water between sampling sites in this study. Melo et al. (2003), investigating the resilience and stability of streams, verified that small environmental changes do not drastically affect the 


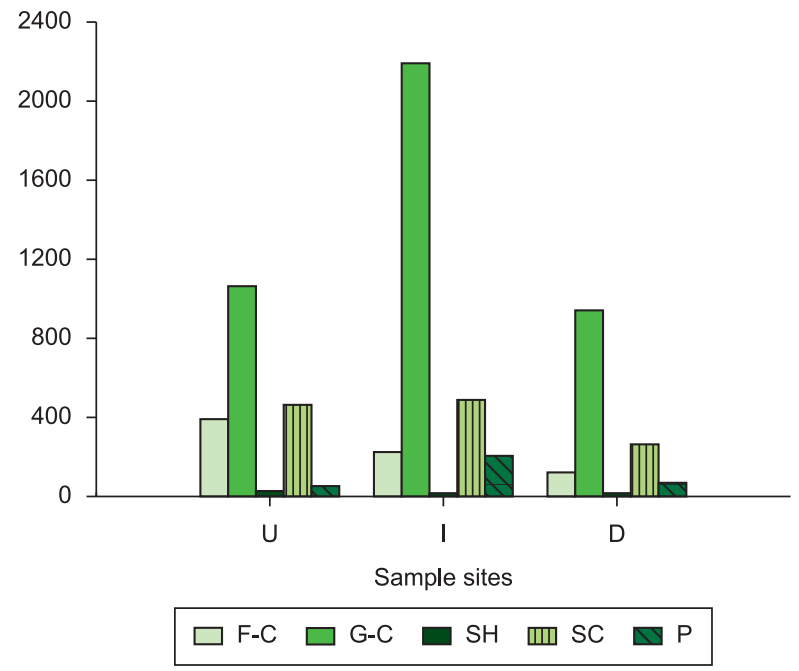

Figure 5. Density (ind. $\mathrm{m}^{-2}$ ) of functional groups in the different sampling sites of Itiz Stream. (F-C = filtering-collector; G-C = gathering-collector; $\mathrm{SH}=$ shredder; $\mathrm{SC}=$ scraper; $\mathrm{P}=$ predator, $\mathrm{U}$ : upstream, I: intermediate, $\mathrm{D}$ : downstream).

habitat and its quality, nor the richness of the assemblages. This fact explains the non-significant variations for the attributes of the benthic macroinvertebrates community between the different sampling sites. When analyzing environmental variations in the microhabitats, the main aspect creating differences was the presence of litter in the pools of greater depths, with these pools also favoring a higher accumulation of fine particles of sediment. According to Hagen et al. (2006) the morphological aspects of the stream can be modified by the organic matter inputs and also the associated fauna.

The number of taxa registered in this study reflects the pattern verified for preserved tropical streams. Thus, the taxonomic richness is high in comparison to environments of the same size subjected to more pronounced human actions. A study conducted by Mormul et al. (2009) in an impacted river, the Ivaí River watershed, the same as the present study, found only 14 taxa, whereas Milesi et al. (2009) registered 47 taxa in seven streams in Rio Grande do Sul State, with different degrees of impact. In the present study, we recorded the occurrence of a probable new genus and species of Ostracoda, Cyprididae family, whose representatives are common and abundant in vegetation and topsoil (Visser \& Veldhuijzen van Zanten 2010). Moreover, we emphasized the presence of taxa typical of small lotic environments, which reinforces the importance of this type of approach, mainly in regions where there is a scarcity of studies on benthic communities, confirming patterns described in the literature.

Among the most abundant taxa in this survey, aquatic insects were prominent, constituting one of the most important groups of invertebrates that comprise the benthic fauna, especially for its high abundance and diversity (Higuti et al. 1993). Chironomidae is prominent among benthic insects, given its high abundance, biomass and diversity in several continental environments (Higuti et al. 1993, Coffman \& Ferrington Junior. 1996, Callisto et al. 2002, Moretto et al. 2003, Higuti 2004, Takahashi et al. 2008). Furthermore, the larvae of this family are very important for the maintenance of nutrient cycling and trophic webs in aquatic ecosystems (Armitage et al. 1994). The high abundance of Chironomidae, in Itiz Stream was mainly due to the taxa adapted to lotic environments, such as most of Lopescladius, Thienemaniella, as well as Rheotanytarsus. The latter are common on the surface of rocks, since they attach their tubular nest in order to filter food particles (Henriques-Oliveira et al. 1999).
Ephemeroptera, Plecoptera, Trichoptera (EPT) and Coleoptera are characteristic of flowing water, and rocky and sandy bottoms with accumulation of litter. These invertebrates, especially the EPT, are known by their high sensitivity to human action and their presence along the Itiz stream therefore denotes its good preservation. A study undertaken by Ligeiro et al. (2010b) evidenced that about $90 \%$ of the fauna associated with the litter in streams is made up of these taxa, corroborating the results obtained in our study.

The processes of structuration and functioning of aquatic ecosystems are direct or indirectly influenced by macroinvertebrates, since they are part of the diet of other invertebrates and several vertebrates. In addition, they are an important component in the detritus chain. The higher accumulation of litter, as recorded in the intermediate course, provides an increase of microhabitats, especially for shredders (Gonçalves Junior et al. 2007).

Although the ANOVA results showed no significant difference for richness, density and diversity, we consider that the highest values of these attributes were the result of the flow, and therefore higher oxygenation, of the water in this site. This might have influenced the presence of the genera of Ephemeroptera (Thraulodes), Trichoptera (Chimarra), Chironomidae (Corynoneura) and Plecoptera (Perlidae). So the characteristics of the sampling sites are important factors for the fauna composition, mainly which related to the habitat integrity, as also found by Milesi et al. (2009).

Moreover, the differences between the areas of riffles and pools were well-illustrated by the DCA, which distinguished taxa that were better adapted to more lentic conditions than those taxa from environments with running water, thus evidencing the importance of microhabitats for richness and diversity in small streams. The larger shading area provided by marginal vegetation associated with geomorphological characteristics of the stream contributed to the increase in richness and diversity of benthic macroinvertebrates in these environments.

The fine particulate organic matter (FPOM) is the main food resource used by the gathering-collector (Hoffmann 2005). The high abundance in all sampling sites, mainly in the upstream and intermediate course, was probably related to the higher food availability provided by the substrate, which comprised litter and fine sediments, especially in pool areas. The abundance of other groups was less pronounced in the other regions, as well as differing little between the sampled stretches, probably due to the stream size (first order).

Classifying macroinvertebrates into functional groups has been very useful to understanding the patterns of organisms' distribution in streams. While many of these invertebrates may present a higher plasticity, according to food availability in the environment (Bagatini et al. 2010), in general one realizes that the occurrence patterns of functional groups is in accordance with the assumptions set by the river continuum concept (RCC) (Vannote et al. 1980).

The macroinvertebrate community, in general, is one of the components of lotic systems that best reflect the degree of biotic integrity. Environmental impact may result in reduced biodiversity and changes in functional structure of this community (Kleine \& Trivinho-Strixino 2005). The complex interactions between benthic fauna and the environment make these organisms useful tools in the evaluation of water quality and the development of biological indices (Nijboer et al. 2005, Roche et al. 2010). The use of these metrics for monitoring streams is in wide use today, and has been adapted to suit regional and local differences, especially when comparing preserved and impacted environments.

High values of richness and diversity, coupled to BMWP indices, evidenced that Itiz Stream can be considered an environment of excellent quality from its upstream to downstream stretches. 
These attributes of benthic community are probably related to the physical, chemical and structural characteristics of the stream here studied. The fact that this environment is a first order stream, with riparian vegetation along almost its entire course, and away from the surroundings of urban centers, contributes to its environmental quality. Monteiro et al. (2008) also observed an improvement in water quality in sampling sites of Meia Ponte River basin, Goiás State, which were more distant from populated areas. In addition, the Itiz Stream presents microhabitats with riffles and that are welloxygenated, favoring the permanence of more sensitive taxa, such as Ephemeroptera, Plecoptera and Trichoptera, which increase the BMWP scores (Biasi et al. 2008). A similar relationship is found in some studies undertaken in tropical streams (Junqueira et al. 2000, Buss \& Vitorino 2010).

Biological monitoring of aquatic ecosystems, mainly the smaller ones that suffer most intensely from the human actions associated with urban and agricultural expansion, facilitates the management that is of fundamental importance to preserving these ecosystems and the faunal integrity. In Itiz Stream, the presence of preserved riparian vegetation that increases the input of allochthonous organic matter available for the fauna, and the distance from pollution-generating urban centers, probably contributed to its high water quality in all sampled sites of the stream. Accordingly, the faunistic survey and the increased knowledge of the structure of benthic communities contribute to filling the gap in studies of this nature in the region. Furthermore, we note the need for further research about remaining areas of preserved environment, to determine local and seasonal patterns that might characterize, or even interfere with, the biological integrity of these environments.

\section{Acknowledgements}

The authors would like to thank the Centro Universitário de Maringá (CESUMAR) for financial and logistic support; to everybody who helped in field activities; and Jaime Luiz Lopes Pereira for preparing the map.

\section{References}

ABEL, P.D. 1989. Pollution biology. In Biological monitoring of inland fisheries (E. Horwood, E. Chichester \& J.S Albaster, eds.). Applied Science Publications, London, 266p.

ALBA-TERCEDOR, J. 1996. Macroinvertebrados acuáticos y calidad de las aguas de los rios. In Simpósio Del Agua em Andulacía - SIAGA. Almeria, v.2, p.203-213.

ARMITAGE, P., CRANSTON, P.S. \& PINDER, L.C.V. 1994. Chironomidae: Biology and ecology of non-biting midges. Chapman and Hall, London.

BAGATINI, Y.M., BENEDITO, E. \& HIGUTI, J. 2010. Effect of the environmental factors on the caloric content of benthic and phytophilous invertebrates in neotropical reservoirs in the Paraná State, Int. Rev. Hydrobiol. 95:246-259.

BAPTISTA, D.F. 2008. Uso de Macroinvertebrados em Procedimentos de Biomonitoramento em Ecossistemas Aquáticos. Oecol. Bras. 12(3):425-441.

BIASI, C., MILESI, S.V., RESTELLO, R.M. \& HEPP, L.U. 2008. Ocorrência e distribuição de insetos aquáticos (Ephemeroptera, Plecoptera, Trichoptera) em riachos de Erechim/RS. Perspectiva. 32(117):171-180.

BRINKHURST, R.O. \& MARCHESE, M.R. 1991. Guia para la identificacion de oligoquetos acuaticos continentales de sud y Centroamérica. Asociación Ciencias Naturales del Litoral, Santo Tomé, 207p.

BUSS, D.F., BAPTISTA, D.F., NESSIMIAN, J.L. \& EGLER, M. 2004. Substrate specificity, environmental degradation and disturbance structuring macroinvertebrate assemblages in neotropical streams. Hydrobiologia. 518(1-3):179-188. http://dx.doi.org/10.1023/ B:HYDR.0000025067.66126.1c
BUSS, D.F. \& VITORINO, A.S. 2010. Rapid bioassessment protocols using benthic macroinvertebrates in Brazil: evaluation of taxonomic sufficiency. J. N. Am. Benthol. Soc. 29(2):562-571. http://dx.doi. org/10.1899/09-095.1

CALLISTO, M., MORENO, P., GONÇALVES JÚNIOR, J.F., LEAL, J.J.F. \& ESTEVES, F.A. 2002. Diversity and biomass of Chironomidae (Diptera) larvae in an impacted coastal lagoon in Rio de Janeiro, Brazil. Braz. J. Biol. 62(1):77-84. http://dx.doi.org/10.1590/S1519-69842002000100010

COFFMAN, W.P. \& FERRINGTON JÚNIOR, L.C. 1996. Chironomidae.In An introduction to the aquatic insects of North America (R.W. Merritt, \& K.W. Cummins, eds.). Hunt Publishing, Kendall, p.635-754.

COSTA, C., IDE, S. \& SIMONKA, C.E. 2006. Insetos imaturos. Metamorfose e identificação. Editora Holos, Ribeirão Preto.

CUMMINS, K.W., MERRITT, R.W. \& ANDRADE, P.C.N. 2005. The use of invertebrate functional groups to characterize ecosystem attributes in selected streams and rivers in south Brazil. Stud. Neotrop. Fauna E. 40:69-89. http://dx.doi.org/10.1080/01650520400025720

FERNÁNDEZ, H.R. \& DOMÍNGUEZ, E. 2001. Guia para ladeterminación de los artrópodos bentónicos sudamericanos. Universidad Nacional de Tucumán, San Miguel de Tucumán.

GONÇALVES JUNIOR, J.F., GRAÇA, M.A.S. \& CALLISTO, M. 2007. Litter decomposition in a Cerrado savannah stream is retarded by leaf toughness, low dissolved nutrients and a low density of shredders. Freshwater Biol. 52:1440-1451. http://dx.doi.org/10.1111/j.13652427.2007.01769.x

GUIMARÃES, R.M., FACURE, K.G., PAVANIN, L.A. \& JACOBUCCI, G.B. 2009. Water quality characterization of urban streams using benthic macroinvertebrate community metrics. Acta Limnol. Bras. 21(2):217-226.

HAGEN, E.M., WEBSTER, J.R. \& BENFIELD, E.F. 2006. Are leaf breakdown rates a useful measure of stream integrity along an agricultural land use gradient? J. N. Am. Benthol. Soc. 25(2):330-343. http://dx.doi. org/10.1899/0887-3593(2006)25[330:ALBRAU]2.0.CO;2

HEINO, J., PARVIAINEN, J., PAAVOLA, R., JEHLE, M., LOUHI, P. \& MUOTKA, T. 2005.Characterizing macroinvertebrate assemblage structure in relation to stream size and tributary position. Hydrobiologia. 539:121-130. http://dx.doi.org/10.1007/s10750-004-3914-3

HENRIQUES-OLIVEIRA, A.L., SANSEVERIANO, A.M. \& NESSIMIAN, J.L. 1999. Larvas de Chironomidae (Insecta: Diptera) de substrato rochoso em dois rios em diferentes estados de conservação na Mata Atlântica, R. J. Acta Limnol. Bras. 11(2):17-28.

HIGUTI, J. 2004. Composition, abundance and habitats of benthic chironomid larvae. In The upper Paraná river and its floodplain: physical aspects, ecology and conservation (S.M. Thomaz, A.A. Agostinho\& N.S. Hahn, eds.). Backhuys Publishers, Leiden, p.209-221.

HIGUTI, J., TAKEDA, A.M. \& PAGGI, A.C. 1993. Distribuição espacial das larvas de Chironomidae (Insecta, Diptera) do rio Baía (MS-Brasil). UNIMAR, 15(suplemento): 65-81.

HOFFMANN, A. 2005. Dynamics of fine particulate organic matter (FPOM) and macroinvertebrates in natural and artificial leaf packs. Hydrobiologia. 549:167-178. http://dx.doi.org/10.1007/s10750-005-5174-2

JUNQUEIRA, M.V., AMARANTE, M.C., DIAS, C.F.S. \& FRANÇA, E.S. 2000. Biomonitoramento da qualidade das águas da Bacia do Alto Rio das Velhas (MG/Brazil) através de macroinvertebrados. Acta Limnol. Bras. 12(1):73-87.

KLEINE, P. \& TRIVINHO-STRIXINO, S. 2005. Chironomidae and other aquatic macroinvertebrates of a first order stream: community response after habitat fragmentation. Acta Limnol. Bras. 17(1):81-90.

LENAT, D.R., SMOCK, L.A. \& PENROSE, D.L. 1980. Use of benthic macroinvertebrates as indicators of environmental quality. In Biological monitoring for environmental effects (D.L. Worf, ed.). D.C. Heath, Lexington, p.97-112.

LIGEIRO, R., MELO, A.S. \& CALLISTO, M. 2010a. Spatial scale and the diversity of macroinvertebrates in a neotropical catchment. Fresh Biol. 55:424-435. http://dx.doi.org/10.1111/j.1365-2427.2009.02291.x 
LIGEIRO, R., MORETTI, M.S., GONÇALVES JUNIOR, J.F. \& CALLISTO, M. 2010b. What is more important for invertebrate colonization in a stream with low-quality litter inputs: exposure time or leaf species? Hydrobiologia. 654(1):125-136. http://dx.doi.org/10.1007/s10750-0100375-8

LOYOLA, R.G.N. 2000. Atual estágio do IAP de índices biológicos de qualidade. In Simpósio de ecossistemas brasileiros: Conservação. ACIESP, v.1: Conservação e Duna, n.109, p.46-52.

MAGURRAN, A.E. 1988. Ecological diversity and its measurement. Chapman and Hall, London.

MARTENS, K. 1995. Recente non-marine Ostracoda.In Workshop OnNeotropical Aquatic Invertebrates. USP, São Paulo, 18p.

McCAFFERTY, W.P. 1988. Aquatic Entomology: the Fisherman's and Ecologists' Illustrated Guide to Insects and their Relatives. Jones \& Bartlett Publishers, Sudbury.

McCUNE, B. \& MEFFORD, MJ. 1999. PC-ORD. Multivariate Analysis of Ecological Data. MJM Software, Gleneden Beach.

MELO, A.S., NIYOGI, D.K., MATTHAEI, C.D. \& TOWNSEND, C.R. 2003. Resistance, resilience, and patchiness of invertebrate assemblages in native tussock and pasture streams in New Zealand after a hydrological disturbance. Can. J. Fish. Aquat. Sci.60(6):731-739. http://dx.doi. org/10.1139/f03-061

MERRIT, R.W. \& CUMMINS, K.W. 1996. An introduction to the aquatic insects of North America. Kendall/Hunt Publishing Co., Dubuque.

MILESI, S.V., BIASI, C., RESTELLO, R.M. \& HEPP, L.U. 2009.Distribution of benthic macroinvertebrates in subtropical streams (Rio Grande do Sul, Brazil). Acta Limnol. Bras. 21(4):419-429.

MONTEIRO, T.R., OLIVEIRA, L.G. \& GODOY, B.S. 2008 Biomonitoramento da qualidade de água utilizando macroinvertebrados bentônicos: adaptacão do índice biótico BMWP' à bacia do rio Meia Ponte-GO. Oecol. Bras. 12(3):553-563.

MORETTO, Y., HIGUTI, J. \& TAKEDA, A.L. 2003. Spatial variation of the benthic community in the Corumbá reservoir, Goiás, Brazil. Acta Sci. 25(1):23-30.

MORMUL, R.P., PRESSINATTE JUNIOR, S., VIEIRA, L.A., MONKOLSKI, A. \& POVH, E.B. 2009. Caracterização das condições ambientais de um rio neotropical a partir da densidade, composição e riqueza de taxa de invertebrados bênticos. Acta Sci. 31(4):379-386.

NIJBOER, R.C., VERDONSCHOT, P.F.M. \& VAN DER WERF, D.C. 2005. The use of indicator taxa as representatives of communities in bioassessment. Freshwater Biol. 50:1427-1440. http://dx.doi.org/10.1111/ j.1365-2427.2005.01405.x

PECKARSKY, B.L., FRAISSINET, P.R., PENTON, M.A. \& CONKLIN JUNIOR, D.J. 1990. Freshwater macroinvertebrates of northeastern North America. Cornell University Press, USA.

PÉREZ, G.R. 1987. Guía para el estudio de los macroinvertebrados acuáticos del Departamento de Antioquia. Editorial Presencia Ltda, Colombia.
PES, A.M.O., HAMADA, N. \& NESSIMIAN, J.L. 2005. Chaves de identificação de larvas para famílias e gêneros de Trichoptera (Insecta) da Amazônia Central, Brasil. Rev. Bras. Entomol. 49(2):181-204. http:// dx.doi.org/10.1590/S0085-56262005000200002

POFF, N.L. 1997. Landscape filters and species traits: towards mechanistic understanding and prediction in stream ecology. J. N. Am. Benthol. Soc. (16): 391-409.

ROCHE, K.F., QUEIROZ, E.P., RIGHI, K.O.C. \& SOUZA, G.M. 2010.Use of the BMWP and ASPT indexes for monitoring environmental quality in a neotropical stream. Acta Limnol. Bras. 22(1):105-108. http://dx.doi. org/10.4322/actalb.02201010

ROSSETTI, G. \& MARTENS, K. 1996. Redescription and morphological variability of Darwinula stevensoni (Brady \& Robertson, 1870) (Crustacea, Ostracoda). Bull. Kon. Belg. Inst. Nat. Biol. 66:73-92.

ROSSETTI, G. \& MARTENS, K. 1998. Taxonomic revision of the recent and Holocene representatives of the family Darwinulidae (Crustacea, Ostracoda), with a description of three new genera. Bull. Inst. R. Sci. Nat. Belg. Biol. 68:55-110.

STATSOFT INC. 2005. Statistica (data analysis software system). version 7.1 www.statisoft.inc.

SILVA, F.H., FAVERO, S., SABINO, J. \& GARNÉS, S.J.A. 2011. Índices bióticos para avaliação da qualidade ambiental em trechos do rio Correntoso, Pantanal do Negro, Estado do Mato Grosso do Sul, Brasil. Acta Sci. Biol. Sci. 33(3):289-299.

TAKAHASHI, M.A., HIGUTI, J., BAGATINI, Y.M., ZVIEJKOVSKI, I.P. \& VELHO, L.F.M. 2008. Composition and biomass of larval chironomid (Insecta, Diptera) as potential indicator of trophic conditions in southern Brazil reservoirs. Acta Limnol. Bras. 20(1):5-13.

THORP, J.H \& COVICH, A.P. 1991. Ecology and classification of North American freshwater invertebrates. Academic Press, Inc., San Diego.

TRIVINHO-STRIXINO, S. \& STRIXINO, G. 1995. Larvas de Chironomidae (Diptera) do Estado de São Paulo: guia de identificação e diagnose dos gêneros. Universidade Federal de São Carlos, São Paulo.

VANNOTE, R.L., MINSHALL, G.W., CUMMINS, K.W., SEDELL, J.R. \& CUSHING, C.E. 1980. The river continnum concept. Can. J. Fish. Aquat. Sci. 37:130-137. http://dx.doi.org/10.1139/f80-017

VISSER, H. \& VELDHUIJZEN VAN ZANTEN, H.H. 2010. European Limnofauna. http://nlbif.eti.uva.nl/bis/limno. php?menuentry=soorten\&id=119 (último acesso em 08/02/2010).

WANTZEN, K.M. \& WAGNER, R. 2006. Detritus processing by invertebrate shredders: a neotropical-temperate comparison. J. N. Am. Benthol. Soc. 25:216-232. http://dx.doi.org/10.1899/0887-3593(2006)25[216:DPBI $\mathrm{SA}] 2.0 . \mathrm{CO} ; 2$

WÜRDIG, N.L., CENZANO, C.S.S. \& MOTTA, D.M. 2007. Macroinvertebrate communities structure in different environments of the Taim Hydrological System in the state of Rio Grande do Sul, Brazil. Acta Limnol. Bras. 19(4):57-68. 